\title{
Adaptation of the food choice questionnaire - Digitalization of the word association method
}

\author{
BARBARA BIRÓ* (- and ATTILA GERE
}

Hungarian University of Agriculture and Life Sciences, Institute of Food Science and Technology, Villányi út 29-43, H-1118, Budapest, Hungary

\section{CONFERENCE FULL PAPER}

Received: June 3, 2021 • Accepted: July 20, 2021

Published online: August 7, 2021

(C) 2021 The Author(s)

\begin{abstract}
In the last decade, bread consumption was decreasing in Hungary (from $44.5 \mathrm{~kg}$ to $34.4 \mathrm{~kg} / \mathrm{capita}$ ). Our aim is to identify the factors influencing the consumption of different bread and bakery products, using the Food Choice Questionnaire (FCQ).

FCQ is frequently used to explore factors (e.g., price, packaging, etc.) influencing the purchase of different food products. The adapted version of the FCQ for breads and bakery products is not yet available in Hungarian language. Word association (WA) and triangulation methods are usually used in the adaptation process.

Due to COVID-19, WA method was performed with a newly developed application presenting six photos of breads. This was completed by 193 participants. Responses were analysed using a categorizing triangulation technique, based on which the FCQ was modified.

In this study, we present the implementation and the results of the digitalized WA method and its use in the adaptation process of the FCQ.
\end{abstract}

\section{KEYWORDS}

bread consumption, consumer choice, word association application, online consumer research

*Corresponding author. E-mail: barbarabirophd@gmail.com, biro.barbara.4@phd.uni-szie.hu 


\section{INTRODUCTION}

Carbohydrates are the simplest energy sources to use, the body's essential nutrients, which are found in the largest quantities in plants, including cereals, thus in cereal-based food products. They are classified as energy-providing nutrients, but the indigestible carbohydrate polymers also play an important role in maintaining the normal functioning of the human body, as these dietary fibres can help in controlling body weight, reducing blood sugar and serum cholesterol levels, and reducing the risk of gastrointestinal cancers (Stephen et al., 2017).

According to the data of the Hungarian Central Statistical Office, bread consumption in Hungary fell from $44.5 \mathrm{~kg} /$ person to $34.4 \mathrm{~kg}$ between 2010 and 2018 (KSH, 2018). In addition, the popularity of white bread also decreased, from 76\% to 61\% between 2007 and 2017, according to GFK Hungária (Agrárszektor, 2017). This decrease of bread consumption also reduces carbohydrate intake, which is 45.8 percent of the daily energy intake, based on the 2014 data of the Hungarian Diet and Nutritional Status Survey (Sarkadi Nagy et al., 2017). This is the lower limit of the daily carbohydrate intake recommended by EFSA, which is 45$60 \%$ of the energy intake, and energy shortages from carbohydrates are covered by fats (European Food Safety Authority, 2010). The recommended daily fibre intake is $25 \mathrm{~g}$ to ensure healthy intestinal function (European Food Safety Authority, 2010). In contrast, Hungarians consume only $22.9 \mathrm{~g}$ of dietary fibre a day (Sarkadi Nagy et al., 2017). These factors affect health both directly and indirectly through obesity. However, the consumption of grain products greatly facilitates the intake of the recommended daily amount of fibre, provided by producing wholegrain products, with flours containing the bran part of the grain (Magyar et al., 2020).

Our aim is to identify and explore the factors influencing the consumption of bread, including whole grain breads, using the Food Choice Questionnaire (FCQ). This questionnaire is often used in international research to explore which factors (e.g., price, ingredients, packaging, taste, convenience) influence the purchase of a particular food (Steptoe et al., 1995). The version of the questionnaire adapted for breads is not yet available in Hungarian language, so the aim is to create and validate it. According to the scientific literature, word association (WA) and triangulation methods are used in the adaptation process.

\section{MATERIALS AND METHODS}

The adaptation method of the FCQ was based on the work of Linh et al. (2019).

The used FCQ was the original version developed by Steptoe et al. (1995) (Fig. 1).

\section{The original Food Choice Questionnaire and its translation}

The translation of the questionnaire to Hungarian was performed based on the work of Beaton et al. (2000). The work of two target-language translators (one initiated and one uninitiated) was used to produce two translations. After a consensus, this translation was translated back from Hungarian into English by two native English-speaking translators. The final Hungarian questionnaire was created after comparing this new English version to the original one. 


\begin{tabular}{|c|c|c|c|c|}
\hline It is important to me that the food I eat on a typical day: & 1 - Not important at all & 2-A little important & 3-Moderately important & 4-Very important \\
\hline \multicolumn{5}{|l|}{ is easy to prepare } \\
\hline \multicolumn{5}{|l|}{ contains no additives } \\
\hline \multicolumn{5}{|l|}{ is low in calories } \\
\hline \multicolumn{5}{|l|}{ tastes good } \\
\hline \multicolumn{5}{|l|}{ contains natural ingredients } \\
\hline \multicolumn{5}{|l|}{ is not expensive } \\
\hline \multicolumn{5}{|l|}{ is low in fat } \\
\hline \multicolumn{5}{|l|}{ is familiar to me } \\
\hline \multicolumn{5}{|l|}{ is high in fibre and roughage } \\
\hline \multicolumn{5}{|l|}{ is nutritious } \\
\hline \multicolumn{5}{|l|}{ is easily available in shops and supermarkets } \\
\hline \multicolumn{5}{|l|}{ is good value for money } \\
\hline \multicolumn{5}{|l|}{ cheers me up } \\
\hline \multicolumn{5}{|l|}{ smells nice } \\
\hline \multicolumn{5}{|l|}{ can be cooked very simply } \\
\hline \multicolumn{5}{|l|}{ helps me cope with stress } \\
\hline \multicolumn{5}{|l|}{ helps me control my weight } \\
\hline \multicolumn{5}{|l|}{ has a pleasant texture } \\
\hline \multicolumn{5}{|l|}{ is packaged in an environmentally friendly way } \\
\hline \multicolumn{5}{|l|}{ comes from countries I approve of politically } \\
\hline \multicolumn{5}{|l|}{ is like the food I ate when I was a child } \\
\hline \multicolumn{5}{|l|}{ contains lots of vitamins and minerals } \\
\hline \multicolumn{5}{|l|}{ contains no artificial ingredients } \\
\hline \multicolumn{5}{|l|}{ keeps me awake and alert } \\
\hline \multicolumn{5}{|l|}{ looks nice } \\
\hline \multicolumn{5}{|l|}{ helps me relax } \\
\hline \multicolumn{5}{|l|}{ is high in protein } \\
\hline \multicolumn{5}{|l|}{ takes no time to prepare } \\
\hline keeps me healthy & & & & \\
\hline is good for my skin/teeth/hair/nails etc & & & & \\
\hline makes me feel good & & & & \\
\hline has the country of origin clearly marked & & & & \\
\hline is what I usually eat & & & & \\
\hline helps me to cope with life & & & & \\
\hline can be bought in shops close to where I live or work & & & & \\
\hline is cheap & & & & \\
\hline
\end{tabular}

Fig. 1. The original Food Choice Questionnaire (edited by the authors, adapted from Steptoe et al. 1995) 


\section{The word association method}

In the word association method, respondents are presented with terms/product descriptions/ images related to the topic, after which they have to describe the first 3-4 phrases, associations, images, thoughts, or feelings that come to their mind about the given stimulus (Ares \& Deliza, 2010). Due to the epidemic situation, this method could not be performed offline, therefore we developed an online word association application.

\section{The development of the online word association application}

The application presented six different photos of breads. The code was written in Java (54.4\%), HTML (42.3\%), CSS (2.9\%), JavaScript (0.4\%) programming languages, the recorded data were extracted in .xlsx and .json file formats. The language of the interface was Hungarian. The application was also optimized for mobile devices. The respondents were students at the Hungarian University of Agriculture and Life Sciences, and also recruited in Facebook using the snowball technique.

During the offline method, respondents usually have half a minute to respond. However, based on our trial completions, this time proved to be short for the online responses. Thus, in the finalized questionnaire, there was one minute to describe four associations for each image, after which the application automatically proceeded to the next part of the questionnaire. The six images appeared in random order for each respondent. To make the data easier to process, participants had to enter their associations separated by semicolons.

At the end of the questionnaire, respondents had to answer a series of demographic questions (gender, age, type of residence). At the beginning of the questionnaire, they were informed that no respondents can be identified based on these data.

\section{Triangulation method}

Responses to the WA were analysed using a triangulation technique, in which the associations of the participants were categorized by professionals, first individually and then by consensus (Linh et al., 2019). Based on these categories, the FCQ could be modified by removing categories which are irrelevant in the case of the examined product group and/or by adding new, relevant categories.

\section{RESULTS}

\section{The user interface and the obtained results of word association application}

The final appearance of the application and the responding interface are shown in Figs 2-6.

Thirty-seven males and 156 females participated, the ratios of genders are $19.17 \%$ male and $80.83 \%$ female. The youngest respondent was 18 years old, while the eldest was 66 years old, the average age was $29.91 \pm 8.92$ years. Based on their residence, $55.96 \%$ lived in the capital (Budapest). A total of more than 4,500 phrases were collected about the six images.

The most common terms related to the sensory characteristics of bread (e.g., tasty, soft, brown, white, crispy), to its effects on health and its nutrients (e.g., healthy, unhealthy, fattening, fibrous, gluten) and to its quality and origin (e.g., fresh, rose, dries quickly, home, store) were 


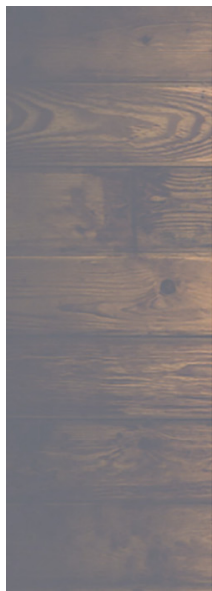

\section{Kedves Kitöltö!}

Biró Barbara vagyok, a Szent István Egyetem Elelmiszertudományi Doktori Iskolájának harmadéves hallgatója. Kutatómunkám során kérdōives és érzékszervi minösitési módszerekkel vizsgálom, milyen faktorok befolyásolják a kenyérfogyasztást hazánkban.

A kitöltés anonim, a felvett adatok alapján a kitöltő személyek nem beazonosithatóak. A válaszadók adatait nem módositjuk, harmadik fél számára nem szolgáltatjuk ki. A felvett adatokat és az eredményeket a Szent lstván Egyetem Érzékszervi Minösitō Laboratóriumában ơrizzūk, a késöbbiekben szakcikk és tudományos elōadás formájában kivánjuk bemutatni.

\section{Kezdés}

Ha kérdése van a kutatással kapcsolatban, a kōvetkező e-mail címeken bōvebb tảjékoztatást kaphat:

barbarabirophdegmailcora

birabarbara.4ephdunissiche

Biró Barbara

PhD hallgato

Szent Istrán Egyetem Elelmlszertudomsnyl Kar

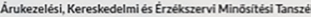

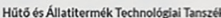

1118 Budapest, Villanni út $29-43$.

Fig. 2. The initial interface of the application

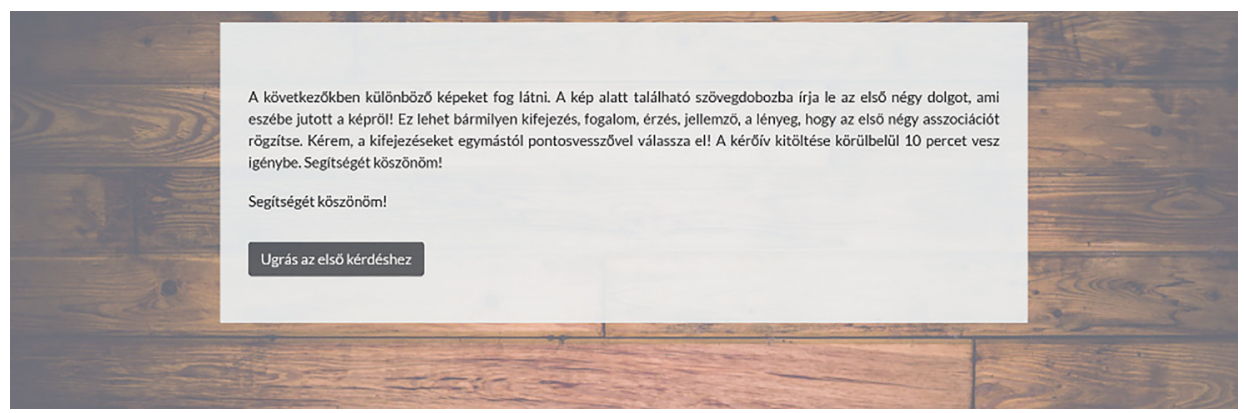

Fig. 3. The instructions for the respondents

related. Many expressions related to the respondent's families and moods (e.g., grandma's bread, my mother's bread, family dinner, childhood memories, Sunday morning). Terms related to bread ingredients (e.g., flour, wholegrain flour, seeds, yeast, preservatives) and other foods associated with bread (e.g., butter, pork fat and onions, goulash, fish soup, egg) were also common. Most of the generally bread-related terms appeared in the case of all pictures. Other terms were usually directly related to the type of bread shown in the picture (e.g., 'preservatives' for packaged toast bread, 'seeds' for the bread with linseeds and sesame seeds, 'holiday' for loaf tied with a national colour ribbon).

\section{The triangulation method}

The data obtained with the word association application were sorted. After deleting the incorrect, incomplete fill-ins, the remaining terms were filtered based on their meaning and then grouped into larger groups. Thus, a total of 691 terms were categorized, first 


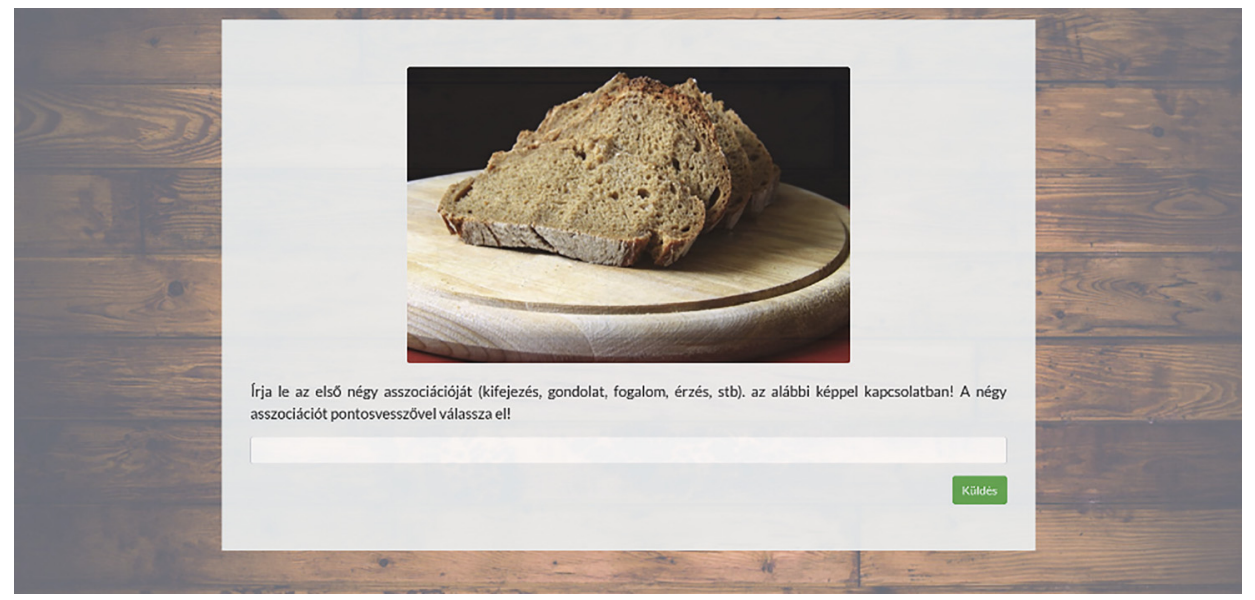

Fig. 4. The responding interface

\section{Demográfiai adatok}

Kor

Nem!

Lakhcly

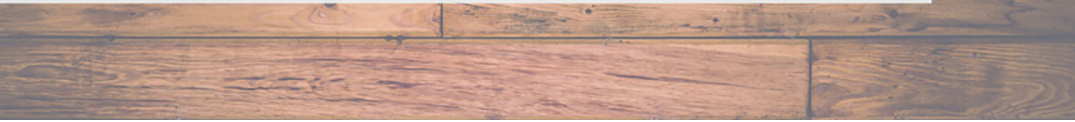

Fig. 5. The interface of demographic questions

\section{A kitöltés befejeződött.}

\section{Segitségét kōszōnōm!}

Biró Barbara

PhD hallgato

Szent Istvàn Egyotem Elelmissertudományi Kar

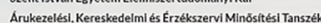

Hũtõ és Âllatitermék Technológial Tanszék

1118 Budapest, Villánylút 29-43.

bartarabirochidermaricom

Dirabarbara.4eondunilszie, he

Fig. 6. The final interface of the questionnaire 
Table 1. Modification of the terms of the original Food Choice Questionnaire based on the Word Association results

\begin{tabular}{|c|c|c|c|c|}
\hline Original terms & Newly added terms & Deleted terms & $\begin{array}{l}\text { Terms required } \\
\text { modification }\end{array}$ & Modified terms \\
\hline keeps me healthy & $\begin{array}{l}\text { can be consumed } \\
\text { in special diets } \\
\text { (e.g., gluten free, } \\
\text { vegan) }\end{array}$ & $\begin{array}{l}\text { contains lots of } \\
\text { vitamins and } \\
\text { minerals }\end{array}$ & is easy to prepare & is easy to use \\
\hline $\begin{array}{l}\text { is high in fibre and } \\
\text { roughage }\end{array}$ & is traditional & is high in protein & is low in fat & $\begin{array}{c}\text { how much } \\
\text { carbohydrate it } \\
\text { contains }\end{array}$ \\
\hline is nutritious & is sliced & $\begin{array}{l}\text { is good for my } \\
\text { skin/teeth/hair/ } \\
\text { nails etc. }\end{array}$ & $\begin{array}{l}\text { has the country of } \\
\text { origin clearly } \\
\text { marked }\end{array}$ & $\begin{array}{l}\text { its producer is } \\
\text { clearly marked }\end{array}$ \\
\hline $\begin{array}{l}\text { takes no time to } \\
\text { prepare }\end{array}$ & is small pack/size & $\begin{array}{l}\text { helps me to cope } \\
\text { with life }\end{array}$ & & \\
\hline $\begin{array}{l}\text { can be bought in } \\
\text { shops close to } \\
\text { where I live or } \\
\text { work }\end{array}$ & is fresh & helps me relax & & \\
\hline $\begin{array}{l}\text { is easily available in } \\
\text { shops and } \\
\text { supermarkets }\end{array}$ & is organic & $\begin{array}{l}\text { helps me cope with } \\
\text { stress }\end{array}$ & & \\
\hline looks nice & $\begin{array}{l}\text { is a type of product } \\
\text { recommended by } \\
\text { professionals (e.g., } \\
\text { a dietitian) }\end{array}$ & $\begin{array}{l}\text { keeps me awake } \\
\text { and alert }\end{array}$ & & \\
\hline smells nice & $\begin{array}{l}\text { comes from a } \\
\text { nearby producer }\end{array}$ & makes me feel good & & \\
\hline tastes good & & cheers me up & & \\
\hline $\begin{array}{l}\text { has a pleasant } \\
\text { texture }\end{array}$ & & $\begin{array}{c}\text { can be cooked very } \\
\text { simply }\end{array}$ & & \\
\hline $\begin{array}{c}\text { contains no } \\
\text { additives }\end{array}$ & & $\begin{array}{l}\text { comes from } \\
\text { countries I approve } \\
\text { of politically }\end{array}$ & & \\
\hline \multicolumn{5}{|l|}{$\begin{array}{l}\text { contains natural } \\
\text { ingredients }\end{array}$} \\
\hline \multicolumn{5}{|l|}{$\begin{array}{l}\text { artificial } \\
\text { ingredients }\end{array}$} \\
\hline \multicolumn{5}{|l|}{ is cheap } \\
\hline \multicolumn{5}{|l|}{$\begin{array}{l}\text { is good value for } \\
\text { money }\end{array}$} \\
\hline is low in calories & & & & \\
\hline $\begin{array}{l}\text { helps me control } \\
\text { my weight }\end{array}$ & & & & \\
\hline
\end{tabular}


Table 1. Continued

\begin{tabular}{|c|c|c|c|c|}
\hline Original terms & Newly added terms & Deleted terms & $\begin{array}{c}\text { Terms required } \\
\text { modification }\end{array}$ & Modified terms \\
\hline $\begin{array}{l}\text { is what I usually eat } \\
\text { is like the food I ate } \\
\text { when I was a } \\
\text { child } \\
\text { is familiar to me } \\
\text { is packaged in an } \\
\text { environmentally } \\
\text { friendly way }\end{array}$ & & & & \\
\hline
\end{tabular}

independently and then by consensus. During the consensus, these categories were compared with the original FCQ categories and terms. As a result, from the 36 terms of the original questionnaire, 11 not-bread-related terms were deleted, 3 terms were modified, and 8 new, bread-related terms were added. Together with the remaining 22 terms, the new, adapted Food Choice Questionnaire consists of 33 terms (Table 1). This questionnaire will be used after the test-retest method, which will provide information about its reliability and repeatability (Dikmen et al., 2016).

\section{DISCUSSION}

Due to the pandemic caused by COVID-19, it has become essential in almost every sector to develop solutions that do not require personal presence, of which research and development is no exception. In the fields of sensory evaluation and consumer science it is difficult to implement, since sensory evaluation tests often need laboratory conditions, and interviews, or focus group discussions take place with personal participation.

According to the guidelines of the Institute of Food Science and Technology, in the case of sensory evaluation tests, it is mandatory to separate the panelists, both during the tests and the evaluation. This is best achieved by keeping the $1.5 \mathrm{~m}$ distance. Disinfection of used equipment is essential. It may be appropriate to use home use tests if the tested product and the methodology allow it.

The same applies in the case of consumer science methods that require a personal presence. It is also possible to perform some methods online or with fewer participants (e.g. focus groups). The advantage of many questionnaires is that they can be completed online, or remotely (Bailey, 2020).

In the case of the WA questionnaire, the key questions were to determine the response time and how to record the data. It was important to have a longer time for responding than the available time in the case of personal presence, as the speed of typing varies from individual to individual. To separate the terms from each other, we had to choose a symbol that is unlikely to be used by respondents in the terms described. It was also key that the application be optimized for smartphones and tablets as well, since nowadays people use them more frequently than computers. 
Overall, based on the answers, the results, and the feedback from the respondents, we successfully digitalized the Word Association method.

\section{CONCLUSIONS}

With the successful digitalization of the Word Association method we carried out a methodological development that allows us to easily and simply perform similar tests even after the epidemic situation is over, since in our accelerated world, consumers are more easily accessible online.

\section{ACKNOWLEDGEMENTS}

BB thanks the support of Doctoral School of Food Sciences, Hungarian University of Agriculture and Life Sciences. AG thanks the support of the Premium Postdoctoral Research Program of the Hungarian Academy of Sciences and the support of National Research, Development and Innovation Office of Hungary (OTKA, contracts No. K134260). Supported by the ÚNKP-20-3II-SZIE-23 New National Excellence Program of the Ministry for Innovation and Technology from the source of the National Research, Development and Innovation Fund. The Project is supported by the European Union and co-financed by the European Social Fund (grant agreement no. EFOP-3.6.3-VEKOP-16-2017-00005).

\section{REFERENCES}

Agrárszektor. (2017). Egyre kevesebb kenyeret eszik a magyar. https://www.agrarszektor.hu/elemiszer/egyrekevesebb-kenyeret-eszik-a-magyar.7899.html.

Ares, G. and Deliza, R. (2010). Studying the influence of package shape and colour on consumer expectations of milk desserts using word association and conjoint analysis. Food Quality and Preference, 21(8): 930-937.

Bailey, K. (2020). IFST sensory \& consumer science guidelines for running testing in response to COVID-19. https://www.ifst.org/sites/default/files/Sensory Consumer Science Research Guidelines in response to COVID-19_with Intro 240920 \%282\%29.pdf.

Beaton, D.E., Bombardier, C., Guillemin, F., and Ferraz, M.B. (2000). Guidelines for the process of crosscultural adaptation of self-report measures. Spine (Phila. Pa. 1976), 25: 3186-3191.

Dikmen, D., Inan-Eroğlu, E., Göktas, Z., Barut-Uyar, B., and Karabulut, E. (2016). Validation of a Turkish version of the food choice questionnaire. Food Quality and Preference, 52: 81-86.

European Food Safety Authority. (2010). Scientific opinion on dietary reference values for carbohydrates and dietary fibre. EFSA Journal, 8(3): 1462.

KSH. (2018). Az egy fóre jutó éves élelmiszer-fogyasztás mennyisége jövedelmi tizedek (decilisek), régiók és a települések típusa szerint (2010-). https://www.ksh.hu/docs/hun/xstadat/xstadat_eves/i_zhc023a.html? down $=1306$.

Linh, L. T., Ai, V. D., Dzung, N. H., and Tam, L. M. (2019). Assessing consumer behaviour towards fish sauce products figure by using food choice questionnaire. Vietnam Journal of Science and Technology, 57(3B): 87-96. 
Magyar, Z., Véha, A., and Szabó, P. B. (2020). Examination of milling technological properties of different wheat varieties. Progress in Agricultural Engineering Sciences, 16(S1): 75-86.

Sarkadi Nagy, E., Bakacs, M., Illés, É., Nagy, B., Varga, A., Kis, O., Schreiberné Molnár, E., and Martos, É. (2017). Országos táplálkozás és tápláltsági állapot vizsgálat - OTÁP2014. II. A magyar lakosság energiaés makrotápanyag-bevitele. Orvosi Hetilap, 158(15): 587-597.

Stephen, A. M., Champ, M. M. J., Cloran, S. J., Fleith, M., Van Lieshout, L., Mejborn, H., and Burley, V. J. (2017). Dietary fibre in Europe: current state of knowledge on definitions, sources, recommendations, intakes and relationships to health. Nutrition Research Reviews, 30(2): 149-190.

Steptoe, A., Pollard, T. M., and Wardle, J. (1995). Development of a measure of the motives underlying the selection of food: the food choice questionnaire. Appetite, 25: 267-284.

Open Access. This is an open-access article distributed under the terms of the Creative Commons Attribution 4.0 International License (https://creativecommons.org/licenses/by/4.0/), which permits unrestricted use, distribution, and reproduction in any medium, provided the original author and source are credited, a link to the CC License is provided, and changes - if any - are indicated. (SID_1) 